\title{
THE COMMUNAL READING OF COMICS: A CASE STUDY OF AN EXTENSIVE READING PROJECT FOR ADULT BASIC LITERACY
}

Esther Ramani and Michael Joseph

University of the North

This paper describes a piece of classroom-centred research we did into the extensive reading practices of adult basic literacy learners. The research reported here was part of a larger research project into the 'communicational' teaching of English for beginning learners inspired by the work of Prabhu (1987). Using comics supplied by The Storyteller Group, we experimented with the Prabhu/Krashen 'acquisition' approach and extended the pedagogy through trial and error, documenting the whole process with the help of videorecordings and our own notes. We present four stages in this 'reading for pleasure' course with descriptions of the pedagogy and excerpts of classroom interaction. Important outcomes of this research are the creative use of language promoted by story re-telling and the desire for ownership of books by learners once they experience ownership of the story through task-based activities on the comics.

Hierdie artikel handel oor klaskamergesentreerde navorsing oor die uitgebreide leesgewoontes van volwassenes wat met geletterdheidsopleiding besig is. Die projek waaroor dit hier gaan vorm deel van 'n groter navorsingsprojek oor die kommunikasiegebaseerde onderrig van Engels vir beginnerleerders en is deur die werk van Prablu (1987) geinspireer. Met behulp van strokiesverhale wat deur The Storytelling Group verskaf is, het ons met Prablu/Krashen se 'verwerwingsbenadering' geëksperimenteer. Die aanbiedingsprosedures is deur gedurige aanpassings verfyn en verbeter en volledig met behulp van video-opnames en ons eie aantekeninge gedokumenteer. Ons beskryf vier fases van hierdie lees-virplesierkursus, aangevul deur metodologiese aantekeninge en uittreksels uit die klaskamerinteraksie. Belangrike uitkomste van hierdie navorsing is die kreatiewe gebruik van taal wat deur die leerders se oorvertel van die stories bevorder is en hulle begeerte om boeke te besit sodra hulle, as gevolg van die take wat op die strokiesverhale gebaseer is, eienaarskap van die storie aanvaar het.

\section{INTRODUCTION}

In this paper, we report on a piece of classroom-centred research we conducted into extensive reading (reading widely for pleasure) with a group of adult learners in Johannesburg in 1995. The learners were in a language acquisition project that we had voluntarily set up called the Communicational Teaching of Adults Project (CTAP). The extensive reading component of our project was an unplanned response to our learners' own needs, articulated halfway through the project, and to a meeting with Peter Esterhuysen of the Storyteller Group, then located in Johannesburg. 
The case for extensive reading is all the more compelling today when viewed against the backdrop of the frustration that teachers experience with what is widely termed the 'death of a reading culture'. At all levels of the education system, teachers embrace the educational goal of learners reading widely and autonomously but feel helpless in achieving this goal. It is common to find teachers complaining that learners are no longer interested in reading, that literature classes are futile because learners do not read the prescribed books (let alone buy them!) and that learners do not venture into anything outside the prescribed curriculum. These arguments are made in particular about black learners in educationally-impoverished contexts. Other reasons advanced are the dominance of television, the non-availability of books and their high cost. Rarely however, do teachers blame the curriculum itself, or the approach to reading implicit in it, because this would tend to shift responsibility on to the system and away from the learners and resources.

Our belief, based on our experience of learners in both India and South Africa, and across the educational spectrum, is that learners are usually motivated to read if the curriculum favours a reading programme that values the life experiences of the learners. We also believe that initial reading experiences, especially of adult learners in a basic literacy programme, need not be based entirely on simplified readers but on a natural use of adult material, or what has been called the 'real books approach'. There is nothing particularly new in such a belief. However, we have found hardly any reports of classroom experimentation based on such a belief. We will describe an embryonic reading programme based on naturalistic reading. The paper is not meant to be a report of a rigorously-tested hypothesis, but more a personal account of two teachers' experience of a spontaneous innovation. At the end of this paper we present some of our insights, which could form the basis for more systematic research.

We originally presented this paper as a poster at the annual conference of the English Language Educational Trust in Durban, and then at Zeke Mphahlele's eightieth birthday celebration at the University of the North, both in 1999. We re-presented it in a different format at the Easy Reading for Adults (ERA) conference in Johannesburg in 2000. To retain the visual mode and the vividness of an oral presentation, in keeping with the media of comics, we have organised this paper as a commentary on the three posters, which made up our presentation. It is therefore important for readers of this article to refer repeatedly to the poster material, which intersperses the text. We will contextualise each poster and then comment on the significance for us of the material we have included in the poster. We have chosen also to retain the spontaneity of the spoken voice in this paper.

\section{POSTER 1}

\section{Contextualising Poster 1 Comment on the title: "The Communal Reading of Comics"}

The 'communal reading' part of the title of our poster is based on a hypothesis of Peter Esterhuysen (a leading member of the Storyteller Group and more recently associated with the work of the Handspring Puppets and the popular though controversial TV production Yizo Yizo). His hypothesis is that reading and storytelling in African culture is done in groups. Based on informal observations he had made during school and community visits to promote 
comics in the 80s and early 90s (Napper and Esterhuysen 1989; Esterhuysen and Napper

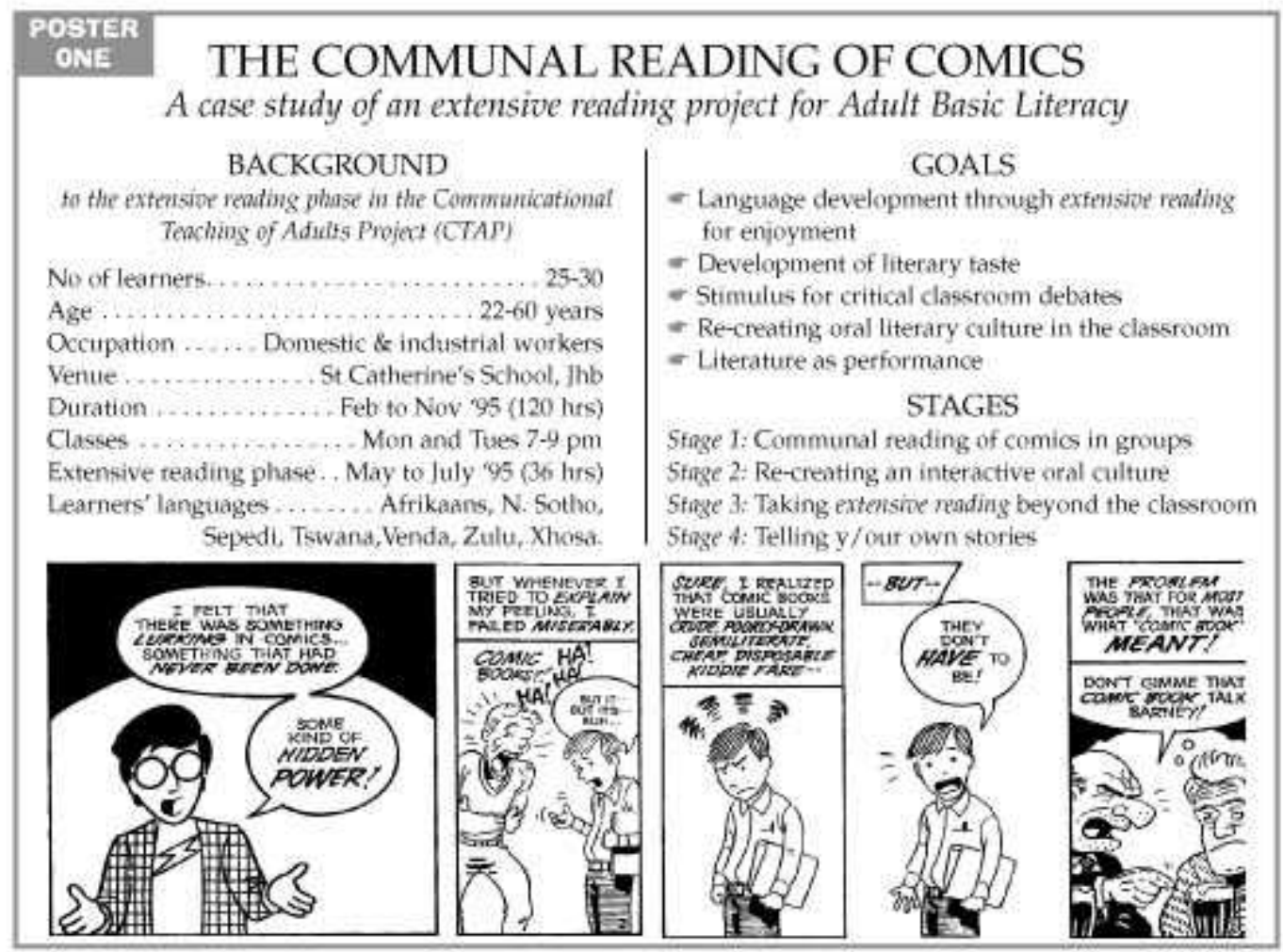

1990)), he found that readers often abandoned their own copies of comics and gathered around one copy held by one person. Reading and discussion then happened naturally around the single copy.

Esterhuysen's question was 'Should not classrooms reflect a community's natural and preferred reading habits?' He speculated that communal reading might prove to be a more motivating strategy for African learners than individual, silent private reading. We were interested in seeing if this indeed happened with our own adult learners.

The 'comics' part of the title was again influenced by Esterhuysen's challenge that comics because of their combination of the verbal and the visual - would be easier and more interesting for all readers but particularly beginner readers, than other print material (such as books, which relied only on the verbal element). We came to learn that a number of highquality comics had been produced by the Storyteller Group and other Non-Governmental Organisations (NGOs) as well, but teachers resisted, or were suspicious of using these in formal education.

Our own informal survey of the use of comics in Adult Basic Education and Training (ABET) organisations in and around Johannesburg showed that even the most progressive NGOs were indifferent to the use of comics. The indifference (to comics and to all readingfor-pleasure material) seemed to derive from the trend, then (as now) to focus on functional literacy, best represented in the creative materials produced by the English Literacy Project (ELP), another NGO that closed down in the mid-90s. An exception was the Easy Readers for Adults (ERA) project, an NGO which focussed on reading for pleasure and which provided reading packs that were graded linguistically for different levels of adult learners. 
As our own project, CTAP, was open (at the level of materials and research hypotheses) to other NGOs' needs to trial their materials, we enthusiastically took on Peter Esterhuysen's hypothesis on communal reading and his promotion of comics for literacy development.

Comment on the sub-title: 'A case study of an extensive reading project for Adult Basic Literacy'

The invisibility of comics inside classrooms is only a part of the invisibility of classrooms themselves. The visible part of education: syllabi, textbooks, examinations and policy documents do not capture the most essential part of education: the processes of teaching and learning in the classroom, The interactions between teachers and learners and among learners around reading materials has been called the invisible or 'hidden curriculum' (Barnes 1976). A case study for us meant describing what happens in the classroom as vividly, accurately and comprehensively as possible. Such descriptions would allow us and others who witnessed the project to derive theory from within, so to speak. As we could not find other adult literacy classes experimenting with comics, we became more determined to document our experiments with the reading of comics among our own adult learners. We thus have several video recordings of learners reading and interacting around comics as well as samples of their own writings produced around comic material.

\section{Comment on the comic excerpt from Scott McCloud (1960)}

Four years after we conducted our case study described above, we were compelled to reflect more carefully on our experiment, as our move to the University of the North confronted us once again with the dire need for reading and for books among our own students. We began to read more widely about the use of comics in education. We came across the interesting book by Scott McCloud (1993), which uses the comic mode to tell us about the invisible art of comics. This book and the paper by Shirley Brice Heath and V Bhagat (1997), mentioned in Poster 2, strengthened our positive beliefs about the value of comics inspired by Peter Estherhuyzen and our own classroom experiments. To the depth of the case study was thus added the breadth of international scholarship.

The comic has come a long way to enjoy respectability as a genre in its own right. Scott McCloud's comic book on comics shows that though there are 'bad' comics, they 'don't have to be'. The comics produced by the Storyteller Group, and other NGOs in South Africa represent the best African literature stories, by pioneers of the African literary renaissance, and are technically brilliant as well. Poster 2 shows the outer covers of these comics. We used all of them in our ABET class.

We used the excerpt from McCloud in Poster 1 to reflect on our own subversive reading of comics at home and in school (such as camouflaging comics inside the covers of an atlas or even reading comics under the bedcovers). When we shared our subversive comic reading past with other educationists at the Durban conference and at the Zeke Mphahlele conference (held at UNIN in August 1999), many smiled empathetically and confessed to similar experiences. The Heath and Bhagat article (see Poster 2) talks about a South African writer, Mathabane, who started his life as a reader with comics and went on to read literary and scholarly works later in life. 
Of the five goals listed in Poster 1, the first goal 'language development through extensive reading for enjoyment' fell squarely within the main goal of our project: the unconscious acquisition of language through exposure to the target language. This principle was developed by NS Prabhu in the early 80s and argued in his book Second Language Pedagogy (1987). Krashen, whose work is very well known through his numerous publications (1985 and others) argues for unconscious acquisition through the provision of 'comprehensible input'. Another scholar who has argued for pleasure reading as a form of play is Nell (1988).

Prabhu believed and demonstrated in a five-year classroom experiment in primary schools in India that when learners grapple with the meaning of texts the mind would at a subconscious level construct a grammar. Conscious attempts to teach a grammar were not only ineffective but harmful for language acquisition. Applying this insight to the comic reading experiment, we believe that the more pleasure learners derived from reading, the more they would read for meaning without paying conscious attention to the details of language structure. Such reading has been referred to as 'extensive reading' or 'reading for pleasure' and is similar to the kind of reading that advanced users of a language naturally do in informal, non-classroom contexts. For ABET learners, such reading would result in exposure to large amounts of language and in assimilation of larger stretches of meaning as compared to the reading promoted in functional literacy through the use of simplified texts.

The other four goals: 'development of literary taste', 'stimulus for debates', 're-creating the oral literary culture in the classroom' and 'literature as performance' were new goals that we evolved in the process of trying to establish the reading of comics in the classroom. They were therefore additions to the original goal of the project (namely 'language acquisition'). Of these four goals, the one of 'recreating oral culture' turned out to be the one that most influenced the successful practice of reading. It is therefore described in greater detail in Poster 3. This goal was most fully realised in Stage II of the classroom methodology we evolved .

\section{Comment on 'Stages' of the Extensive Reading Course}

Stage I: Communal reading of comics in groups: This was a try out of Peter Esterhuysen's hypothesis on communal reading. Students were organised into groups and asked to choose a comic. Each group was given only one copy of the comic selected. We found many varying practices in the groups. In one of them, the oldest (and obviously most respected member of the class, 'Gogo Rosie') took on a teacherly role and read the comic out loud, explaining each frame, sometimes using Zulu. In another group we found learners taking on the personae of the characters in the comic and doing role plays. In yet another group, learners took turns reading aloud and discussing the comic at the same time.

But what came as a surprise to us was that very shortly after this communal reading experience, learners wanted the comic to read privately in their own time after class. Towards the end of the course they even demanded their own copy of these comics and were ready to pay for them. It seemed to us that the communal experience provided a successful entry point into reading but learners were eager to move to a private, autonomous mode. 
Stage II: Re-creating an interactive oral culture: The core of the project, where reading was made into an interactive, problem-solving activity, and 'storying' led to 're-storying'. This stage is discussed more deeply later in this paper.

Stage III: Taking extensive reading beyond the classroom: Here learners read the same story but through other media: short story, a play, and an interview with the comic producer. For example, the learners on our project, after reading the comic version of Can Themba's The Suit, went on to read the short story version, watched a dramatic performance of it fortuitously staged by Drama students at Wits in mid 95 - and conducted an interview with Peter Esterhuysen on how the comic had been constructed.

Stage IV: Telling our own stories: Teachers and learners narrated stories from their own life that sprung from associations with the stories in the comics. Some students went on to write their own stories.

We believe now that Stages I and II are essential for a reading programme and stages III and IV are desirable but not always predictable or feasible.

\section{Comment on 'Background'}

The logistical information provided here shows how varied adult learner classes can be. The linguistic grading of reading materials is often defeated by such learner variation. Also note that the extensive reading course took up about one third of the total of $120 \mathrm{hrs}$, the other two thirds being devoted to a problem-solving approach to functional literacy content. This onethirds of the time for reading is significant because the learners wanted more reading and did not see it as time wasted in relation to 'functional' literacy. Our own doubts about the duration of the extensive reading experiment (arising no doubt from the strong utilitarian functional literacy paradigm that permeated ABET) were thus dispelled.

\section{POSTER 2}

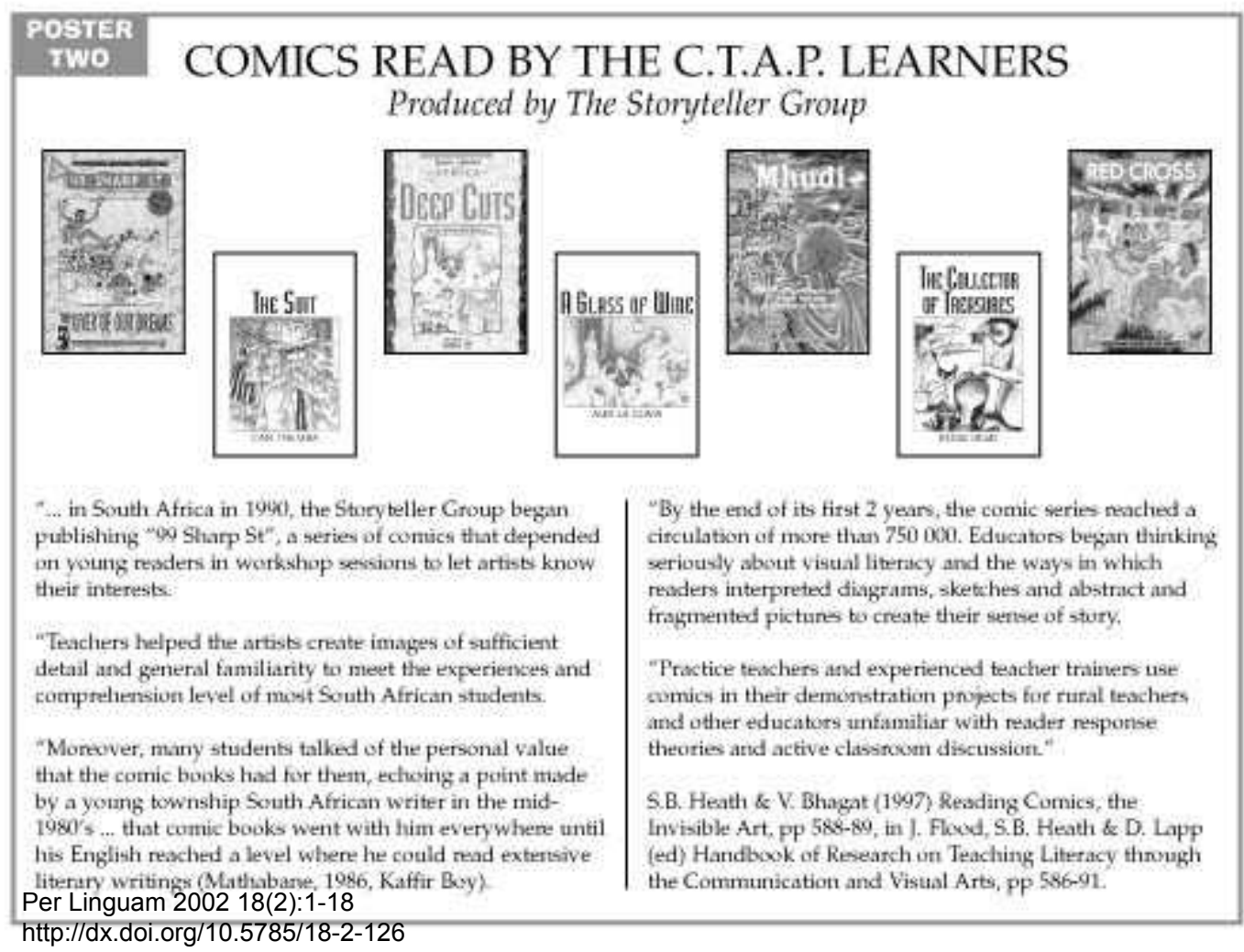




\section{Contextualising Poster 2}

As mentioned earlier in this paper, Poster 2 shows the cover pages of the comics read by the CTAP learners. In addition to the hugely popular The River of our Dreams, our learners read all three stories in Deep Cuts and even took on the very challenging comic of Sol Plaatjie's Mhud'. Some read The Red Cross with much diligence. What is not shown on the poster is the comic version of the biblical story of Mary, which the Storyteller Group was piloting in a draft form at the time. The comic was called Mary, Mother of Jesus and in reading this comic with our learners, we experienced a high level of enthusiasm and eagerness to re-live the stories that they were already familiar with.

We designed a number of problem-solving tasks around the comic, which drew on their previous knowledge, and predictions about what would appear in the comic version. Students also compared a few frames in the comic with the original biblical version.

What we discovered was that in the early days, our learners were not very discriminating and were happy to read whatever fell into their hands. At the end of the project, they bought up (at a concessional rate) every copy we had of Deep Cuts and Mhudi. Their eagerness to own the books they had enjoyed, and their ability to exercise choice, was unexpected and remarkable!

The excerpts in Poster 2 from the Heath and Bhagat article (1997) were meant to provide background on the Storyteller Group and to capture the experience of comic readers in South Africa. We, as well as the audiences we presented our poster to, were amazed at the extraordinary success that comics have had in some small pockets of the (largely non-formal) educational system.

\section{POSTER 3}

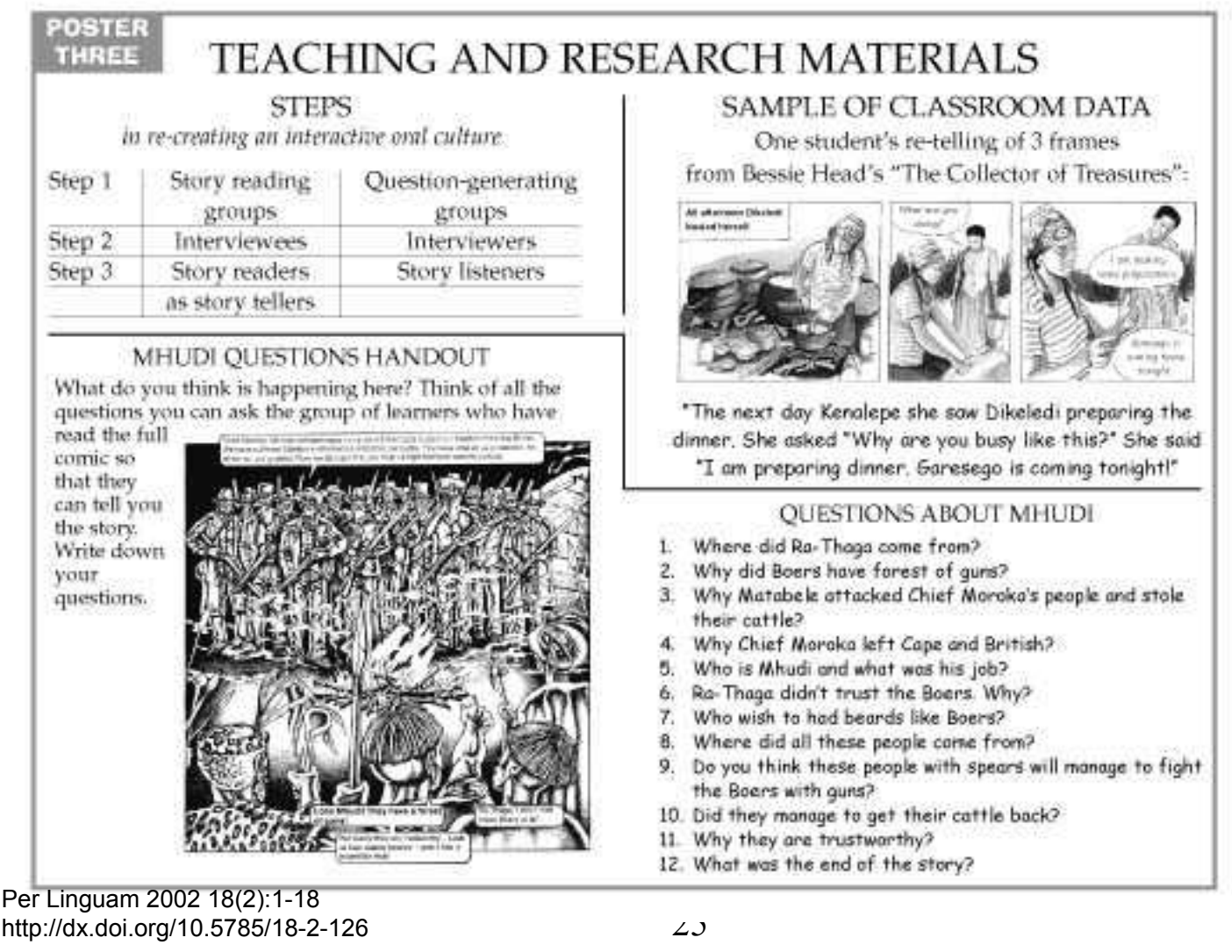




\section{Contextualising Poster 3}

This poster presents a sample of the teaching and research materials generated on the extensive reading project. As already mentioned, we saw Stage II of our methodology: Recreating an interactive oral culture in the classroom as a central anchor of the classroom procedures we developed. Stage II consisted essentially of three steps:

Step 1 involved dividing the learners into two groups: the story reading groups and the question-generating groups. For example, one group of learners was given the comic Mhhudi to read, while another group was only given one page from the middle of the comic. This group was instructed to generate any questions they wanted based on the visuals and text on the single page. As can be seen from the questions generated by this group, the learners had 'real' questions to pose, as they had no previous knowledge of the characters or events in the story.

The questions posed on Can Themba's The Suit from one page of the comic included questions like 'Is "the fellow" the same as the suit?', 'Why must the visitor sleep with them?', and 'Why does the man want to share all that they have with a stranger?'. The questions on the Mhudi comic (shown in Poster 3) also reveals that the questions come from a desire to know who the central characters are, what the crucial incidents are and how the story develops.

These are very different from the kind of comprehension-testing questions that teachers typically ask. The question 'What was the end of the story?' is a lively evidence of the value of the in medias res strategy. This strategy throws the question-generating group right into the heart of the story and compels the group to generate questions that both look back and forward.

In Step 2, the question-generating group took on the role of interviewers and asked questions of the story-reading (interviewee) group. This forced the story-reading group in Step 3 to become story tellers, thus returning the text they had read to the oral mode. The questiongenerating group in turn became story listeners, who exhibited the curiosity, empathy and the desire to know 'What happened next?' that marks the authentic story-telling event.

Given below is a brief extract from a transcript of Steps 2 and 3 around Bessie Head's story, The Collector of Treasures. The teacher is mediating the interaction between the questiongenerating group and the story-reading group. The question-generating group has just listed thirteen questions that they would like to ask the story-reading group, based on a single page of the comic. T refers to Teacher, L1, L2 and L3 refer to individual learners and LL to a collective or choral response produced by several learners simultaneously. At the point where the transcript begins, the teacher is asking the question-generating group to say which is their most important question.

T: $\quad$ So what would you say is the most important question that you would like to ask from these thirteen questions ... which is the question that you feel is very interesting and important?

L1: $\quad$ My question is, "Why does Dikeledi thinking go ...thinking go back her wedding ... her wedding ... her wedding ..." 
LL: "to her wedding day"

L1: $\quad$ "to her wedding day"

T: $\quad$ "to her wedding day". Question 10:"Why does Dikeledi think back to her wedding day?" You think that's an important question? Okay.

10 Would you like, Michael, Joan and Paulina, would you like to tell them what the answer to that is. Tell the story so they can understand.

L2: Because Dikeledi ... she was a ... in a prisoner. Now after she married ...then she find a problem in her marriage because this husband leave him ...leave ... leave her ... and then she kill him and then the other people ask her what has happened to you, why you here, and she answer them but she she think back to her wedding day ... what her wedding was like ... it was very nice at that time ...now that time she just think back and now she got the children and she must think also about the children ...

L1: Who's the father of the children?

L2: Garesego Mokopi.

T: Do you understand ...do you know what was Dikeledi's crime? Michael, do you have anything to add to what Paulina has said?

L3: No, actually you see the reason why Dikeledi think back about her wedding just because...

(four minutes of sustained speech by L3 follows)

There are many interesting things happening here that we can comment on but what we would like to focus on are the following:

1. We discovered through the classroom data which we had collected (videotapes converted into transcripts of the interactions, an example of which is seen above) that the story readers retelling stories are engaging in a constructive and creative act. They do not simply reproduce verbatim the text that they read in the comic. This can also be seen from the extract in Poster 3 that shows a sample of classroom data. The poster shows three frames from Bessie Head's The Collector of Treasures and below it is one learner's reconstructive rendering of the actions and dialogue in the three frames.

2. Secondly, the learner is forced to re-encode in exclusively verbal form a text that is encoded in both visual and verbal modes. This involves producing language that does not appear in the text and therefore taps the learner's own language resources. He is not only rendering the visual into the verbal, but also making explicit the invisible (the 'gutter', that is the implied 'story' that connects one frame with the next) that challenges the learner's imagination and language resources. This thinking and 
language activity is what Prabhu (on whose ideas the Communicational Teaching of Adults Project is based) calls problem solving requiring high cognitive demand, which is the basis of a 'task-based syllabus'. This kind of imaginative cognition is also at the core of Vygotsky's work, in which language and thought are believed to mutually develop each other. This deployment of one's own resources (of thinking and speaking) serves to strengthen the productive capacity ( as against only the receptive capacity found in silent, individual reading) of the learner, which is so central to language acquisition.

3. Thirdly, the learner does not use only indirect (or reported speech) to convey the events in the story. Instead, he makes up dialogue between the two characters in the episode and thus infuses it with his own imaginative and dramatic insight.

4. Fourthly, story telling provokes unplanned and spontaneous questions, as can be seen in line 21 above. This reveals the curiosity and authentic engagement that learners bring to the interactive experience.

5. Fifthly, learners who have read the story compete to tell their version of the story. In line 25 above, L3, after suggesting he has nothing to add, launches into his own version of the story and speaks without pause for four full minutes. This seems to suggest that the desire to 'tell it as I see it' is a powerful urge drawing upon learners' own life experiences and interpretative resources.

6. Finally, learners strive to produce more accurate and faithful accounts of the stories they have read. Their concern for veracity and authenticity leads to re-reading and retelling.

\section{GENERALISATIONS?}

It would obviously be foolhardy to hazard generalisations on the basis of so brief an experiment. What we offer here are rather insights and hypotheses that need to be explored in other contexts.

1. We believe that a strong case needs to be made for the value of comics at all levels of the educational system. Both as an entry point into 'a reading culture' and as a pleasurable ongoing activity that can carry on throughout a reader's lifetime, comics are a resource whose potential is still to be exploited.

Comics in English and African languages of literary classics and popular stories (legends, myths and folklore) would, we believe, offer a sound basis for developing a reading culture.

2. The act of storytelling and re-telling is a powerful motivation for reading. In other words, the conversion of the written word into the oral mode (or returning text to its oral origins) offers the basis for an engaging and viable methodology for reading development. 
3. The demand to own books represents a shift in the learners' own identity. By becoming possessors (and not just readers) of books, learners experience themselves as becoming members of a literate or reading community.

\section{CONCLUSION}

Our brief experiment with extensive reading via comics in an ABET class revealed to us the potential of the story telling approach for promoting reading. The fact that learners wanted to possess their own copies of the comics showed us that while communal reading was a good starting point, learners wanted to be able to read independently and autonomously.

We also found a viable way of promoting reading that could go beyond a language-activities approach (which reduces texts to their factual and linguistic content) as well as a literary approach (as in university courses) whose aim is to develop aesthetic and critical appreciation. However we believe that both language use and literary sensibility can be developed as a by-product of our approach.

Finally, learners from impoverished literacy environments can use story telling as a resource in their own communities to promote literacy. When they perceive themselves as readers, they can use their new-found confidence to develop the literary skills of other members of their community. This is a worthwhile vision to hold in our minds even when we conduct small-scale interventions in the lives of adult learners.

\section{ACKNOWLEDGEMENTS}

We acknowledge with great pleasure the inspirational role of Peter Esterhuysen, who first introduced us to the work of The Storyteller Group, to Neil Napper for his creative re-construction of our poster and to all the learners on the CTAP, who participated so enthusiastically in the reading project and for the public use of the videotaped lessons.

\section{REFERENCES}

BARNES D. 1976. From Communication to curriculum. Harmondsworth, Essex: Penguin Books

ESTERHUYSEN P AND N NAPPER. 1990. 1,000,000 comic books: A proposal for effective intervention The Storyteller Group, Johannesburg.

FLOOD J, SB HEATH \& D LAPP (ed.). 1997. Handbook of research on teaching literacy through the communication and visual Arts. Prentice Hall International.

HEATH SB AND V BHAGAT. 1997. Reading comics, the invisible art. In J Flood et al (eds): 586-591.

JOSEPH M AND E RAMANI. 2002. Turning non-readers into book lovers. Paper presented at the Spring lectures, University of the North, September 2002.

KRASHEN, S. 1985. The input hypothesis: Issues and implications. London: Longman. 
MCCLOUD, S. 1960. Understanding comics: The invisible art. New York: Harper Periennial.

NAPPER, N AND P ESTERHUYSEN. 1989. Popular visual literature. Johannesburg: The Storyteller Group

NELL V. 1988. Lost in a book: The psychology of reading for pleasure: needs and gratifications. New Haven: Yale University Press.

PRABHU, NS. 1987. Second language pedagogy. Oxford University Press.

THE STORYTELLER GROUP. 1993. Deep Cuts: Graphic adaptations of stories by Can Themba, Alex la Guma and Bessie Head. Cape Town: Maskew Miller Longman.

\section{Biographic Note}

Esther Ramani and Michael Joseph teach in the Academic Development Unit at the University of the North. The have done extensive research into literacy. (email: ramanie@unorth.ac.za) 